\title{
The Effect of Educational Modules Strategy on the Direct and Postponed Study's Achievement of Seventh Primary Grade Students in Science, in Comparison with the Conventional Approach
}

\author{
Abeer Rashed Alelaimat \\ Assistant Professor, Al-Balqa Applied University, Princess Rahma College, Salt, Jordan \\ Tel: 962-777-338-756 E-mail: mohammedolimat29@yahoo.com \\ Khowla Abd Al_Raheem Ghoneem \\ Assistant Professor, Al-Balqa Applied University, Princess Rahma College, Salt, Jordan \\ Tel: 962-777-489-756_E-mail: khowlagh@yahoo.com
}

Received: February 1, 2012 Accepted: March 6, 2012 Online Published: April 25, 2012

doi:10.5539/hes.v2n2p40

URL: http://dx.doi.org/10.5539/hes.v2n2p40

\begin{abstract}
This study aimed at revealing the effect of educational modules strategy on the direct and postponed study's achievement of seventh primary grade students in science, in comparison with the conventional approach. The sample of the study consists of (174) male and female students randomly chosen from schools in the city of Mafraq, students are divided into two groups: Control and Experimental. Researchers have developed an educational materials relevant to carry out modules strategy for teaching scientific concepts in the science text book for primary seventh grade, though the development of achievement test to measure the direct and the postponed achievement by the study's sample. The consistency and reliability of the test have been obtained.

The study's results revealed that students in the experimental group are superior over students in the control group in both types of achievement. At the same time results showed the lack of difference between male and female students in direct and long-term achievement test.

Based upon the study's results, researcher recommends the necessity to use more modern means to teach students the "Science" domain such as modules strategy, to hold courses and workshops for teachers training on implementing modules strategy. Furthermore, to make available textbook and references which facilities this style of teaching. Finally, is to conduct similar studies over different domains, such as physics and mathematics.
\end{abstract}

Keywords: Modules, Direct achievement, Postponed achievement

\section{Introduction}

Learning is considered to be one of the most important features and characteristics that play a significant role in nation's progress, whereas it affects positively and comprehensively in rising new generations while relying on modern and advanced scientific foundations. This progress is measured by the extent of educators' knowledge of teaching methods, means and theories; also on their knowledge with modern teaching orientations.

Scientific progress has added many more means which teachers may benefit from in preparing interaction opportunities with learners' experience, sharing and reviewing such experience for the purpose of preparing students with high level of competency (Tobaji, 1981:5). In this context Tobaji (1986) points out that, teacher's function is not only restricted on explanation and following the conventional approaches, but his primary responsibility has become to draw a layout of teaching strategies with teaching approaches and means in order to achieve specific objectives. (Tobaji, 1986: 24)

Barakat, L; points out to the conventional way in teaching and learning by saying, "this approach must be changed in order to meet the educational objectives and achieve its contemporary goals through its responses towards the situations and physical, motor and psychological growth stages, furthermore, to fulfil learners' need within their greatly increased numbers. Bloom and singer agreed that, "there are many approaches which operate in an integrated manner to deal with curriculum and enrich the educational process, stimulate learner's mind in a way that helps in 
being attentive to the instructions process, focus, comprehension and recalling. (Affat, 1990:79)

Furthermore, nowadays are characterized by information and communication revelation, in which discoveries and scientific theories and their technological applications are rapidly evolving in a way that humans never experienced before. This era is characterized by being fully dependent on human mind, fine electronics, and rapid flow of information through computer technology and communication which has eliminated place variable and almost time variable too. In addition to economic globalization and the elimination of cultural variance, as a result of this magnificent changes, it is very essential to respond to it through the development of social organizations with all its types forms and sizes including educational establishments which carry top priority to be developed in order to keep pace with the nature of this era and to respond the transformations in every of life aspects.

Within variables that have affected education, as a response, the educational centres have been filled with learning books, materials and software which facilitate the teaching and learning processes.

In addition, new innovations such as communication means and devices have been employed effectively in education in order to overcome many of problems relevant to education in our days as a result of economic, financial and social factors such as population drastic increase, the number of learners have been also increased drastically in different school cycles, cognitive explosion and the insufficient number of qualified teachers. For all those reasons the utility and employment of non-conventional approaches in education have increased dramatically for the purpose of enhance and increase the education process efficiency along with thinking development. Furthermore, to enhance student skills, due to the increased complexity of the world that resulted from challenges imposed by information and communication technology. Consequently, to be successful in facing such challenges is through the know-how of knowledge use, not by the amount of knowledge.

Schools have found itself in a situation where they must respond to the technological revolution and reflect in their programs this technology elements and to benefit from this revolution product in activating its operations and achieve their goals and schooling education benefits of high-tech to plan and develop their curriculum implement, evaluate and develop such curriculum in order to keep pace, with the demands and requirements of the present time. We need to think about searching information sources and information types in order to deal with current problems. Thinking right begets benefits, especially in education. In 1929 educator Alfred Whitehead said, "Everything you had learned would be useless if you do not put your books aside, burn your lectures notes and forget what you learned quite well for exam". Whitehead means that the educators' real fruit is cognitive processes generated from studying any branch of knowledge not in the accumulated information from that branch. Educators agree that the best teaching approaches are the ones which lead to a good education and help teachers to succeed in initiating the desired changes among students. (Allaqani 1976: 178-179)

Research indicates that there is a no universal approach for teaching, and no method of educational methods is better than the others except in certain circumstances. Current education practises may be invalid nowadays; Perhaps conditions in the past in teaching students were restricted on teacher- Blackboard and text book. While nowadays we have population and cognitive explosions. Thus, people are forced to resort to self learning programs, technology employment. Consequently, the need has risen to rely upon teaching approaches which are far from conventional ways of teacher as well as school. And to be more proper to IT era and the module is one of this progress means. (Traci, 2001)

Educators agree that the best teaching approaches is the one which lead to better education, and help teacher to succeed in initiating the favored changes with students, furthermore, this teaching approach includes planned procedures which teacher utilizes in dealing with his students in order to make education easy and smooth (Laqani,

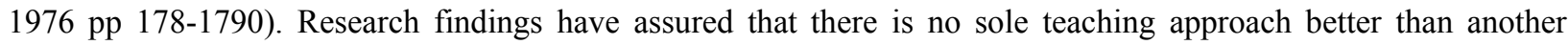
except under certain circumstances, current educational practices may be invalid nowadays because of the circumstances and considerations of old, are no longer the same, especially if we take into account the determination framework for most current practices which is the relationship between teacher- background and text book - under the current teaching practices abilities shall be weak for confronting two expansions : knowledge and population, to fulfill individuals aspiration and hopes that are increasingly expand and getting larger, consequently, result in self-education programs and utilize the technology and clarify its role in the teaching system which provides the different presentation opportunities especially regarding the texts. (Jabber, 1983: p246), therefore the need arisen for the teaching approaches that are far from conventional approaches of school and the teachers, are more suitable for the modern age of information technology and the module approach is considered the modern approach of development ( Traci, 2001) quoted from (radhwan and the others:2004:5)

Therefore the teaching institutes try to find the most affective way in teaching increasing numbers of students in as lower cost and less time as possible, and to cover the lack of number of the qualified teachers, the countries world 
wide used the modern technology in teaching in order to solve the education problems, this lead to invention of new ways and methods to produce an effective type of education and to prepare teachers qualified methodologically and educationally to walk along this vast advanced technology, one this methods is the use of self-education ( individual) with its different types (Jaraddat, 1985).

The subject of individualization of education captured the interest of many of the educationists and Psychologists in the recent years, the take great interest in the individual differences of the learners believing that this learner id unique and special, and teaching is individual process, as a result of this new approach new teaching methods has brought this teaching process from the teaching subject and the dependency on the teacher into the teaching process and giving attention to learner who became the center of activities which aim at archiving the objectives of the teaching process for the learner, these approaches explain that the teaching makes the teaching material more understandable and more resistible to oblivion, helps the learner to individual learning, helps him to gain the thinking strategy, the increase the mental activeness for the learner, and strengthen the motivation, consolidating the self satisfaction and helps to keep what they learned, as they organize the information in his own way (globe, 1988).

There are recently group of individual teaching approaches depending of individualizing the teaching process as modules, this word (MODULE) is of Greek origin and means piece of music and in Arabic means piece of methodology, the module approach is known as modern education method and way of teaching in the early 1960s for the twentieth century, presented be (Weistilait) as audio recordings as teachers preparations for activities supplementary to the text books

The mostly used nowadays small teaching unit (modules) (Jamil, 2000 A D) which is a small teaching unit adopting the principle of self- education strategy and individualization of education, the unit includes specific objectives and learning experiences and activates which is done in logical sequence and complementary to help the learner to achieve the goals and develop the proficiency according the levels which is set previously according to the speed of the self-learner. "Rashed 1408 Hijri, pp 146-159".

The main educational basics of preparing the modules methods:

i. System approach is used (inputs, processing, outputs).

ii. The positive of the learner in the education process according to his speed and abilities ...etc.

iii. The learning is objective and the texts is divided into small steps with objectives

iv. Variety of the experiences, diversity of methods and activates.

v. Being adequate in its content and serve the self education.

vi. Individualization of teaching and consolidating and feedback after each small step.

vii. The positive and active participatory in learning and freedom of movement during education and choosing the teaching material which are suitable for the leaner.

viii. Staring with pre-test and ends post test.

ix. The logical sequence of the whole teaching steps

$\mathrm{x}$. The strategy of modification to perfecting the education.

Fields of using the modules in the educational methods:

i. The educational module can be used in different fields, some of which James Russell mentions:-

1) Tape voice recording for the teaching material prepared by the teacher.

2) Written copy of the original teaching material recorded on the tape.

3) Some reading of the specific pages of the text for each teaching objectives.

4) The assistance of one student to the other in executive activities in the module.

5) Referring to the teacher for guidance and support as needed by the teaching situation.

ii. Enriching the activity of teaching and learning:

Presenting subjects to the students with high abilities and highly motivated for learning to follow up the study to achieve more knowledge to enrich their education by self-learning.

iii. Therapeutic teaching:

Used for students who have difficulties in learning as the increase of number of student sin the classroom and the teacher may not pay attention to all the students in the classroom. 
iv. Teaching certain introductory behavior:

Some modules are designed to develop the introductory learning or a requirement for previous subject or new text to be mastered.

v. Teaching the absent students some subjects:

To give the absent students some teaching modules to teat the teaching subject they missed for some reason, to be achieved by self learning.

vi. Teaching by correspondence for attend the classroom

Steps to design the teaching module:

When designing the methodology of the module there are sequential steps with common relationship among them as follows:

i. The title of the module: to be clear, specific and represent the main idea of the module taking into consideration the time and the age of the student.

ii. The introduction of the module: to motivate and encourage the students to read and giving a general idea about the subject and what to achieve.

iii. Goals: to be clear specific and short suitable with the time and clarifies the expected behavior to be achieved after finishing the study of the module. General goals are divided into behavior objective in each module.

iv. The pre-test and the key answers: the test here determines the level of the student according to the behavior objectives set previously. The pre-test is used alongside the post-test to determine the range of success of the student to pass to the next module after checking his answers with the key answer and the corresponding marks accompanied with each module, in case of failure, has to keep studying the module.

v. Organization of the content of the module:

The content is divided into clear secondary factors and ideas which help the student to understand them easily and presented in many forms with many references to be suitable with the capabilities and tendencies of the student. The content of the module could be written as a whole within the module or the student is referred to some resources and references for further acquaintance of the subject of the module.

To organize the content, it will be engineered in many logical ways according to the nature of the material and the characteristic of the students, whom the module is designed for such as, from simple to the complicated, from the known to the unknown, from facts and partial information (separated) to the laws and complete relations and from the whole to the part and from old to the modern...etc.

vi. Activities and teaching utilities: each module consist of group of diversity of teaching practices enabling the student to choose from what suits him from application and referral activities to achieve the required goals with the support of the variety of the teaching utilities including audio, visual, video and touch, the teaching resources with its capabilities with the tools and equipments.

vii. The chosen recourses and references: in the last pages of the module there will be annex for the reading of the printed and picture material of the book and the reference in the different fields in addition to the list of the references and resources for the student for further expansion to enrich his information about the subject.

viii. The post-test: it is another form of the pre-test or has some new items related to the behavior objective of the subject which is written previously. In case of passing the student moves to the next module, if failed the student has to study the same subject again till he passes (Al-shirbini, Tanawi: previous reference pp 143-151)

The characteristics of the methodology of the teaching module:

i. Allows the student for the positive self-learning and provides time for discussion.

ii. Being far from routine and can study anytime anywhere.

iii. Takes into account the individual and environmental differences among the students.

iv. Encourages the positive participation.

v. Learning with purpose in the life of the students.

vi. Connection and integration among the subjects.

vii. Looking after the scientific thinking skills and searching methods.

viii. Group interaction among the students. 
ix. The teacher is the leader, guide, developer, and the encourager.

$\mathrm{x}$. Modification is a self process with meaning (Hamil, previous reference:p49)

\section{The Problem of the Study}

It is noted that the method used in teaching is the conventional method which is mainly depending on the one source who is the teacher, this does not comply with the technology development, there should be some focus on the student too, and to provide a chance to participate in the teaching process, to become an active factor in it.

To retain, display, and flow of information. This requires the use of comprehensive library and information centers.

The teaching modules are methodological way in thinking and organized way in working handling all the factors included in the teaching process, due to the importance of developing the methods of teaching the science and paying attention to it as part of means of executing the curriculum and achieving its goals by carrying its different content and activities and moving from method of teaching the science from the conventional method to modern concept, the idea of applying the method of modern and diversity teaching method, such as modules method and strategy. The problem of the study can be formed as follows:-

What is the impact of using the strategy of the modules in the direct and postponed achievement in the science subject compared with the conventional method?

\section{The Importance of the Study}

The importance of the study arises from its interest in one of the modern teaching methods that depends on the stimulation of the student thinking for self- learning.

Therefore the researcher hopes to make this study useful in achieving the following:

i. Contributing in improving the teaching of the science subject.

ii. Assistance in training the science teachers and the supervisors in teaching the science subject.

iii. Holding courses by the ministry of education, and workshops for the training on the modern teaching methods including the module method.

\section{The Goals of the Study and the Questions:}

The study aim at showing the module strategy in the direct and postponed achievement in the science subject for the seventh elementary grade in Jordan compared with the conventional method, it intends to answer the following questions:

i. Are there differences with statistic significant at $(a) \leq 0.05)$ in the achievement of the students of the seventh elementary grade in the science subject for the direct post test are related to teaching method (modules, conventional)?

ii. Are there differences with statistic significant at $(a \leq \leq 0.05)$ in the achievement of the students of the seventh elementary grade in the science subject for the direct post test are related to sex?

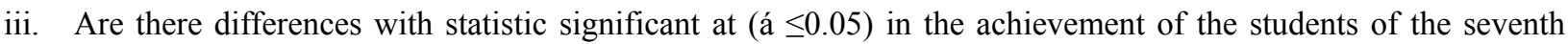
elementary grade in the science subject for the direct post test are related to interaction teaching and the sex?

iv. Are there differences with statistic significant at $(\mathbf{a} \leq 0.05)$ in the achievement of the students of the seventh elementary grade in the science subject for the postponed post test are related to teaching method (modules, conventional)?

v. Are there differences with statistic significant at $(a, \leq 0.05)$ in the achievement of the students of the seventh elementary grade in the science subject for the postponed post test are related to the sex?

vi. Are there differences with statistic significant at $(a \mathbf{a} \leq 0.05)$ in the achievement of the students of the seventh elementary grade in the science subject for the postponed post test are related to interaction teaching and the sex?

\section{The Study Terms}

The Module: it is a small teaching unit based on strategy of the self learning and individualization of the education, the unit contain specific objectives, experiences, and certain teaching activities carried out in sequence and logical completion to help the learner to achieve the goals and develop the sufficiency according to the agreed levels specified previously according to the speed of self-learning.

The Achievement: the result I learning in knowledge domain includes direct and future achievement in all its levels. It has been measured by a test which researcher developed and includes (50) items of multiple choice, by which 
learning results are measured by marks which students score in knowledge, comprehension and application levels and the six Bloom's levels of over application for educational objectives in knowledge domain.

The Direct achievement: total score the student obtains in the achievement tests which is conducted right after the completion of the direct experiment.

Postponed (future) achievement: total marks the student obtain in the achievement test which is conducted weeks after the completion of the experiment.

Seventh Grade: education in Jordan is divided into two sequences: first sequence is called primary which lasts ten years, while the second sequence is called secondary that lasts two years. Seventh grade is meant the seventh year of primary education.

Science" means the text book which the ministry of education approves for the seventh grade in Jordan for the year 2011/2012

\section{Limitation of the Study}

The study is conducted over male and female primary seventh grade students at the Abrar Primary school and Usamah Ben Zaid school in Mafraq, these two schools belong to the ministry of education.

Researcher has used a learning module she developed which covers the two units of reproduction and organism classification in the science text book, reliability and consistency of the module are obtained through a panel of experts in teaching methods.

\section{Previous Studies}

Faraj study (1987) the use of the teaching methods in teaching science for the seventh grade of the elementary level as a modern approach of the individual learning, the study aim at measuring the effectiveness of the use of the teaching module, in teaching science in a modern approach in the individual learning of the seventh grade of the elementary level. To achieve the goals of the study, two random groups were chosen from the classes of the $10^{\text {th }}$ grade, 33 for the experimental group and 30 for the control group from the Islamic Al-Moasat school for boys in Iswan, a pre-test was done for the two groups regarding the variation of the study, the change and balance of the environment was chosen which is from the text book of the $10^{\text {th }}$ grade, it was reformed according to the teaching module and taught to the experiment group where as the organized group was taught the same chapter in the conventional way for the period 1-3-1987 to 1-4-1987, then the post test was done for both groups, the study used the following tools to measuring: achievement test in the chapter of the change and balance in the environment prepared by the researcher.

The result of the study showed that there are differences with statistic significant among the average of marks of the students of the two groups experimental and control at the level of 0.01 in the post measuring of the achievement test this difference is for the favor of the marks if the post measuring for the experimental group

Awad study (1994): this study aim at knowing the study of the area chapter using the module and measuring its impact on the achievement of the students of the $11^{\text {th }}$ grade. To achieve the objectives of the study 45 were chosen experimental group and 48 for the control group in the Qos School for girls, a pretest was done for the two groups for the variations of the study, then the area chapter was chosen from the geometry text of the $11^{\text {th }}$ grade and taught by using the teaching modules of the experimental group, and to the control group by the conventional method for the period of 9-3-1994-28-4-1994. Then a post test was carried out. The study used an achievement test prepared by the researcher.

The result of the study showed there are differences with statistic significant among the average of marks of the experimental and control group for the achievement test as an over all at the three knowledge remembering comprehension- application and this difference was for the favor of the experimental group which means that the module is of benefit and effective to raise the level of he gaining for the area chapter

Al-Dsouqi Study (1995): which aimed at building and design of a program based on the teaching modules with multi teaching utilities for the technology teachers in the primary education in the context of the sufficient study, the results of the study refer to the differences with statistic significant among the average of marks of the experimental and control group which was studied with the program based on the teaching modules in carrying out the achievement test and the observation of the scientific performance.

Zaidan Study (1998): which aim at developing the production skills and using some teaching material for the students of the technology classroom at the quality education colleges, the results of the study refer to the differences with statistic significant among the average of marks of the experimental and control in carrying out the achievement test and the observation of the scientific performance for the favor of the experimental group which 
studied using the teaching modules.

Abdul-Sabour and Al-Saeed Study (1998): which aimed at knowing the impact of the teaching modules in developing the comprehension of the students for the teacher at the nature and science colleges for girls, the two groups were trained one with the use of the teaching modules and the other using the conventional method, the results were that there evidential clue for the modules presented for the student to gain from the teacher concerning the teaching theories, the percentage for the post test reached (85.12) the results showed that there was also impact on more understanding of the student of the teacher for the teaching course the percentage was for the post test (82.62).

Rashel (1999) carried out a study aimed at using the modules in teaching the energy and the human work chapter, the two groups were trained, one by using the modules and the other using the conventional method in teaching, the result showed that the teaching module contributed in increasing the scientific performance of the student and modifying their behavior for the energy consumption.

Cabra (1999) carried out a study aimed at teaching the energy forms for the secondary level using the module method in the energy chapter and its forms thermodynamics based on the scientific experiments, the study showed the differences between the two groups for the favor of the experimental group which studied using the teaching modules.

The study of Salamah referred in the study of Omer (2001) investigating the impact of the use of the teaching modules in teaching the science in the achievement study and the creative thinking for the $4^{\text {th }}$ grade of the elementary school, and to achieve that the researcher prepared an achievement test and applied the creative thinking for Mr. Khair Allah, the sample consists of (68) male and female students were evenly distributed tow groups experimental and control, the results showed that there was a grow in the ability of the members of the experimental group (who were trained by using the teaching modules) in creative thinking more than the students who studied in the conventional method.

Rababeh Study (2007): the study was to investigate the strategic impact of the modules based on perfection and investigation of the chemical concepts for the students of the secondary level, the sample consists of (90) students distributed into three groups: the first experimental group whose students study with the perfection teaching modules, the second experimental group whose students study with the investigation study and third group studied in the conventional method.

The analysis result showed differences with statistic significant for the level (á $\leq 0.05)$ among the average of the students marks for the three groups (modules, investigation, ordinary) to understand the chemical concept post test and the differences were for the favor of the modules.

\subsection{The Conclusion for the Previous Studies}

The researcher did not find (as far as she is concerned) studies closely related to this study of the impact of the modules strategies in the direct achievement and postponed in the science subject.

Therefore the researcher presented some studies related to the variables of the independent study (modules) and its impact on the achievement, and it had a positive impact in gaining the scientific concepts as in the study of Awad 1994, Zaidan1998, Al-Dsouqi1995, Abdul Sabour1998, AAL-Rababeh2007, Rashel1999, Cabra 1999, and Salameh.

This study differs from the previous studies where is compares between the strategy of the modules and the conventional method in achieving the direct and postponed scientific concepts, where as the previous studies compared between the strategy of the modules and the conventional method in direct achievement only., in addition that all the studies carried out in fields and places with different in the subject and nature and the scientific material except the study of Salameh choosing the seventh grade but differ as it compared between the modules and the conventional method and its impact on the achievement and creative thinking.

It is noted that there was a lack of research studies at the Arabic and international level which present the modules and its impact in the achievement, hence comes this study to investigate the impact of the teaching modules in the direct and postponed achievement for the students of the seventh grade in the science subject.

\section{Methodology and procedures:}

\subsection{The Study's Population}

Study's population consists of all the seventh grade students at public school in the city of Mafraq for the school year 2011/2012 to each up to (925female, 655male) students.

\subsection{The Study's Sample}

Study's sample consists of all the (174) male and female students from (4) classrooms in the above mentioned two schools. Sample was chosen through simple random sampling approach, sample is divided into two groups: 
- $\quad$ Experimental group: which is the learning group by module strategy. It consists of (39) male and (48) female students.

- Control group: the group learns through the conventional approach. It consists of (37) male and (50) female students.

Table (1) below shows the sample distribution according to school, classroom and total number of students

\subsection{Study's Tools}

In order to implement this study, it requires preparing an achievement test and preparing a learning materials according to module strategy, as explained below:

\subsubsection{Achievement Test}

Researcher has developed an achievement multiple choice test to measure the direct and the postponed achievement in science, researcher followed the following steps in test preparation:-

i. Analysis of learning material content in each lesson: concepts, and major ideas.

ii. Articulation of learning objectives according to the analysis.

iii. Prepare items to measure the described behavior which researcher developed as it is shown in index (3). These items are multiple choices manner, their total number is (50) items which are restricted to recalling, thinking levels and in accordance to waiver and sensi questions classification (Hamdan 1985).

iv. Test instructions that clarify the test objective and answering approach.

v. Validity of test is obtained by a panel of arbitrators.

vi. Test consistency is obtained through application of pilot study of (40) students from the study's populationKoder-Rechrdon formula is used (KR_20) which measures consistency of test items, whereas test consistency coefficient is $(0,87)$ which is considered to be acceptable.

Thus the test is developed to its final form, consists of (50) items, and for the right answer (1) mark for the wrong one is zero. Therefore, the maximum scaring points is (50) while zero is the minimum. (index 30 )

\subsubsection{Module's Learning Materials}

Researcher has followed in organizing and differentiation of learning material, module's strategy principles which are shown below:

A. Name and title of the module determining which is (reproduction of living organisms, and their classification), from the seventh grade science text book, reproduction unit consists of four subjects

i. First topic, asexual reproduction.

ii. Second topic, sexual reproduction.

iii. Third topic, Plant reproduction.

iv. Fourth topic, science, technology, and society.

Living organisms classification unit, consists of three topics

i. First topic, bacteria, eukaryotic kingdom, Fungi Kingdom.

ii. Second topic, plant kingdom.

iii. Third topic, animal kingdom.

B. Behavioral objectives determination:

Each lesson's content has been analyzed; whereas concepts and major ideas have been articulated along with expected learning outcomes (index 2). These objectives are listed at the beginning of each lesson.

C. Essential requirements for subject teaching are determined and the assurance of its availability:

These are represented by knowing the scientific concepts, the use of laboratory and the library.

D. The learning material format which will be administered to students:

Where it is administered to students in a written learning format, which is the subject in the text book that addresses the learner and impose questions which students has to answer. These are followed by self-evaluating questions which the learner must answer. To be sure of correctness of their answers, key answer is by the end of each subject. In addition each subject is provided by a set of exercises which requires the learner to answer the accompanied 
questions.

E. Preparing s study Guide for all subjects:

This guide leads learner to know how to follow the subjects and move one to another subject and how to deal with learning materials and benefit from various learning sources (index1).

A. Determining the mastery standards: it has been determined by using a certain tool, this reached up to 85 percent to move from subject to the next after dividing the learning content into several subjects. This tool has been determined according to the arbitrators' recommendation.

B. Test preparation (passing tests): this type of tests have been prepared in a way to cover all units with a rate of three tests for each subject to another with a mastery rate of 85 percent. Tests are graded in the presence of the assigned teacher or face to face with them.

C. Researcher determined the necessary means and activities to carry out the module such as: video tape talk about the organism's reproduction and classification, in addition to collect relevant pictures and materials.

D. Researchers have developed several activities and applied exercises such as examining the mint plant, looking for horizontal root growing beneath the soil, in addition to activities and exercises relevant to the module.

E. The adding of an index by the end of the module contains references and bibliography which student may need during the module.

F. Researcher submitted learning material and study quick to a panel of arbitrators who are expert in the field in order to azure the extent of its suitability to module strategy.

\subsection{Procedures of the Study}

i. Selection and development of the learning units in accordance with module strategy.

ii. The developed unit for the module strategy to be submitted to the panel of arbitrators, and implement their recommendations.

iii. Experimenting the module strategy develop unit over a sample of students.

iv. Prepare achieving test of multiple choice type and submit it to a panel of expert arbitrators to ensure its validity, their recommendations will be taken into consideration.

v. Experimenting achievement test on a pilot sample from the study's population to ensure its consistency.

vi. Determine the study's sample from the four classrooms.

vii. Visit schools at which the experiment will be carried out, have a meeting with relevant teachers who are the heads of the sample classrooms.

viii. Apply achievement test on the two group (experimental, and control) as a pre-test, in order to ensure the quality of the two groups prior to the experiment carrying out.

ix. Start teaching the experimental group according to module strategy and control group via the conventional approach by the school teachers and researchers' supervision, duration of teaching was three weeks equal to 12 period, both groups finished on the same time.

x. Administer achievement test over both groups directly upon the completion of the experiment. This is called post-test in order to be assured of students gaining in terms of scientific concepts, recorded the findings. Then to administer the exact test after three weeks from the completion of the experiment on both groups experimental and control in order to measure their postponed achievement this is done without student's prior knowledge especially in regard to the date of test or type.

xi. Grading the students' answers directly after the test.

xii. Data collection, conduct statistical analysis to reach findings.

\subsection{Design of the Study}

Semi-experimental approach has been used for the two groups (control and experimental) and direct pre and post testing, and the postponed test too. The study includes two independent variables as it is shown in table (2).

- Teaching approach via two levels ( module strategy and conventional one)

- $\quad$ Student gender (male, female) 


\subsubsection{Dependent Variable}

Student performance in achievement test. There are two dependent variables.

- $\quad$ Direct post achievement test.

- $\quad$ Postponed Achievement.

\subsubsection{Statistical Processing}

Researcher conducted ( $\mathrm{T}$ ) test prior to the experiment in order to ensure equality between the two groups (control, experimental), means and standard deviation and ANCOVA A analysis for post direct test and the postponed.

\section{Study Results}

This chapter dealt with the results of this study related to the module strategy and the conventional way for the achievement of the seventh primary for the scientific concepts, the details are as follows:

The results related to the pre-achievement test:

The results of the ANCOVA A analysis for the two groups for the pre-achievement test.

The researcher applied the test for the students of the two groups of the study before staring the experiment and the ANCOVA was measured, to know whether there are differences with statistical significant among the average of the students marks of the two groups for the achievement test, the researcher used the analysis of the bilateral variation for the two independent samples to test the statistically significant between the average of marks of the students of the experimental group and the average of marks of the students the control group table (3) shows the results of this analysis.

Table (3) shows that (F) value counted as $(0.33)$ and the level of the $S \mathrm{~S}$ is $(0.568)$ this means that there is no statistical significant differences concerning the pre-test, which means that the two study groups are equivalent regarding the information.

As for the fender of the student the (F) value is (2.83) and the level of S S is (0.94) and it is not significant at the level of $(a \leq 0.05)$, which means that there are no $\mathrm{S} \mathrm{S}$ differences between the two study groups in relation to the gender of the students about the pre-test.

The results related to the direct achievement for the scientific concepts, this requires the answer of the first, second, third questions as follows:

1) Are there differences with statistic significant at $(a$ a $\leq 05)$ in the achievement of the students of the seventh elementary grade in the science subject for the direct post-test are related to teaching method (modules, conventional)?

2) Are there differences with statistic significant at $(a) \leq 0.05)$ in the achievement of the students of the seventh elementary grade in the science subject for the direct post test are related to sex?

3) Are there differences with statistic significant at $(a ́ \leq 0.05)$ in the achievement of the students of the seventh elementary grade in the science subject for the direct post test are related to interaction teaching and the sex?

To answer these questions we calculate the ANCOVA of the direct post-test according to the teaching method and gender, the results are at the table (4)

The results of the ANCOVA for the two study groups on the direct achievement test according to the teaching method and gender.

* Statistically significant at the level of $(a ́ \leq 0.05)$

The table (4) shows the difference of the average for the two study groups, where the average of the students marks of the control group (31.89) and the standard deviation (8.64), the average of the students marks of the experimental group (38.38) and the standard deviation (7.68), these differences need test for the statistic significant at the level of (á $\leq 0.05$ ) this used the which is shown in table (5).

table (5) shows that (f) value (27.784) with the statistic significant $(0.000)$ which means that there is difference with the statistic significant at the level of (á $\leq 0.05$ ) due to teaching method, refereeing to table (4) shows the average of the experimental group working with module approach is (38.38) which is higher than the average of the control group by ( 6.5 degree) this difference is of statistic significance, the same table shows that there are no difference with statistic significance $(a ́ \leq 0.05)$ about the direct achievement test due to student gender, interaction between the gender and the approach.

The results related to postponed achievement for the scientific concepts this requires the answer of the questions 
four, five, and six which are as follows:

i. Are there differences with statistic significant at $(a \mathbf{a} \leq 0.05)$ in the achievement of the students of the seventh elementary grade in the science subject for the postponed post test are related to teaching method (modules, conventional).?


elementary grade in the science subject for the postponed post test are related to the sex?

iii. Are there differences with statistic significant at $(a \mathbf{a} \leq 0.05)$ in the achievement of the students of the seventh elementary grade in the science subject for the postponed post test are related to interaction teaching and the sex?

To answer these questions we calculate the ANCOVA of the postponed post-test according to the gender, the results are at the table (6)

The results of the ANCOVA for the two study groups on the postponed achievement test according to the teaching method and gender.

The table (6) shows the difference of the average for the two study groups, where the average of the students marks of the control group (27.36) and the standard deviation (9.1), the average of the students marks of the experimental group (36.51) and the standard deviation (7.81), these differences need test for the statistic significant at the level of $(a ́ \leq 0.05)$ this used the which is shown in table (7).

table (7) shows that (f) value (50.762) with the statistic significant $(0.000)$ which means that there is no difference with the statistic significant at the level of $(a \dot{a} \leq 0.05)$ due to teaching method for the benefit of the students who were taught with the module approach equals (36.51) which is higher than the average of the control group by ( 9.15 degree) this difference is of statistic significance, the same table shows that there are no difference with statistic significance $(a \mathbf{a} \leq 0.05)$ about the postponed achievement test due to student gender, interaction between the gender and the teaching approach, where the (f) value $(0.907)$ with the statistic significant $(0.342)$, where as the (f) value calculated for the interaction between the gender and the teaching approach, it was (0.524) and the statistic significant (0.470)

\subsection{Results Discussion}

\subsubsection{Results Relevant to Question One}

Are there any statistically significant differences at á $\leq 0.05$ in the direct a achievement of scientific concepts among seventh grade students due to learning approach (modules, conventional).

Results revealed the presence of statistically significant at á $\leq 0.05$ among means of student scores who learned the module strategy over those who studied the traditional way in direct achievement. These differences are in favor of student of module strategy which researcher summarizes as follow:

1) Module strategy learning takes into consideration the individual differences among learners; this problem has occupied a big concern among educationists who call or taking this way of teaching and learning into consideration.

2) Due to its important effect on learning outcome module strategy helps in this, because it allows learner to walk in education process and in accordance to student ability and learner efficiency and positive orientation toward learning.

Theories have assured that learner is the center of learning process; successful learning is a mutual process between learner and teacher towards achieving the objectives of the education. According to the module the learner is a self learner as he is the center of the teaching process, and can find within the module the necessary resources of information that can support his learning, so he chooses what is suitable, the learner decides when he will starts and where to begin. He can find in the module what supports his response, encourages his motivation, immediate modification of his response, thus the learner is free and positive.

3) Perfection in the process of learning. As the module is based on specific behavior goals, feedback, therefore the learning is considered a perfection learning as the learner does not move to the next module unless he passes it with achievement level objective of not less than $80 \%$.

To consolidates the correct answer. the behavior school, especially Sikner, emphasized on the correct answer that the learner reaches, the consolidation is considered as important basics of the teaching. The module has direct consolidation through the contents of the module which notices the learner of the correctness of his answer, when the learner finds out that his answer is correct, this is considered a immediate consolidation for that response, the 
module approach can be sued to teach a whole text, of part of it, can be used with some accompanied activities, such as tapes or recordings, or activities with performance. Knowing that the teacher has a role in configuring the module in all stages, guiding and instructing the learners, and giving any support that helps them to overcome any difficulty they might face.

Moreover the teacher has an important role in stipulating the motivation of the learners using the module; this requires that the teacher has sufficient knowledge of the learners and their characteristics, and their advantages and disadvantages (Rababeh, this result agrees what Farraj has reached-1987, Awad-1994 and Rababeh-2007).

\subsubsection{Results Relevant to Question Two}

Is there any difference of statistically significant at á $\leq 0.05$ in the direct achievement of the knowledge concepts for the students of the sixth elementary grade related to the sex of the leaner?

The results of the study show that there is no difference of statistically significant at á $\leq 0.05$ among the average of the marks for the male and the female direct achievement test.

This result can be referred to the identical abilities and preparations for both sexes and the similarity of the social and economical situations for the samples as well as the similarity of the structure of the text for the both sexes, also the conventional methods of raising the males and females has changed and the chances for both males and females become the same.

\subsubsection{Results Relevant to Question Three}

Is there any difference of statistically significant at á $\leq 0.05$ in the direct achievement of the knowledge concepts for the students of the sixth elementary grade related to the interactive learning and the sex?

The result revealed that there is no difference of statistically significant at á $\leq 0.05$ in the direct achievement of the knowledge concepts for the students of the sixth elementary grade related to the interactive learning and the sex.

This could be due to the impact of the both methods in the direct achievement was the same for all the students, if they were males or females, therefore there were no difference for any method on the achievement of males rather that females or females rather that males.

\subsubsection{Results relevant to Question Four}

Is there any difference of statistically significant at a $\leq 0.05$ in the postponed achievement of the knowledge concepts for the students of the seventh elementary grade related to the teaching approach (modules, conventional)?

The result revealed that there is difference of statistically significant at á $\leq 0.05$ in average of marks between the students who studied using the modules and those of the conventional method in the postponed achievement for the students of the sixth elementary grade in the favor of the module approach.

The superiority of the module approach in the postponed achievement can be explained by the features of the modules approach which specifies the objectives form the beginning of each subject which makes the student focus on the basics of the teaching material away from any secondary or unsuitable things, the teaching material is divided into logically sequential subjects from the easier to the harder which makes the students to interact with the teaching situation with greater degree, which lead to keep the information longer time. This result agrees to what have been reached by Dsouqi-1995, Zaidan-1998, Abdul Sabour-1998 and Rabaeh-2007.

\subsubsection{Results Relevant to Question Five}

Is there any difference of statistically significant at á $\leq 0.05$ in the postponed achievement of the knowledge concepts for the students of the sixth elementary grade related to the sex?

The result revealed that there is no difference of statistically significant at á $\leq 0.05$ in average of marks between the (male, female) students in the postponed achievement.

This result can be referred to the identical abilities and preparations for both sexes and the experiences are the same which makes them keep the information in a similar way.

\subsubsection{Results Relevant to Question Six}

Is there any difference of statistically significant at á $\leq 0.05$ in the postponed achievement of the knowledge concepts for the students of the sixth elementary grade related to the approach and the sex?

The result revealed that there is no difference of statistically significant at á $\leq 0.05$ in the knowledge of scientific concepts for the students of the sixth elementary grade related to the approach and the sex.

This might be due to that both approaches had the same impact on all the students. 


\section{Recommendation}

i. Searching for a effective future vision for teaching effecting the relationship between the school and the individual and the community that achieves the effective leaning method.

ii. Paying more attention on how to use the modern teaching approaches by the scientific texts and providing better teaching opportunities for the learners in the different teaching levels.

iii. Carrying out a number of the workshops to train the teachers on the modern strategy of the modules, how the teachers can use it in a scientific way in the classrooms for raise the teaching levels.

iv. The necessity for reviewing the scientific texts and modification of them and include some important aspects through applying the strategy of the modules and enjoying the learning and developing the skills and lessoning the loading into the texts.

v. Supplying the references and books that enriches the science subject and helps carrying out the strategy of the modules.

vi. Focusing on the researches that have importance to develop the teaching methods and connecting them to technology applications in teaching.

vii. The importance to build many teaching modules in many units of the text in the other teaching subjects and finding their impact on the students' achievement.

\section{References}

Abdul sabour, Muna, Alsaeed, Ameena. (1998). The use of the teaching modules to develop the comprehension of the student(teacher) in the girls college of the nature of the knowledge and learning of the sciences and the way of teaching them, the second scientific conference, the Egyptian society for the scientific education, $1^{\text {st }}$ volume.

Afaf Abdul Kareem. (1990). "The teaching for learning in the sports and physical education" Almaareg establishment, Alexandria.

Aldsouqi, Nohammad. (1995). Proposed program with multi-teaching utilities for the technology teacher in the elementary education in the sufficient way of teaching. Ph.D thesis unpublished - education college Al-Munufia University.

Alklob, Bashir: "The technology in learning and teaching processes", $1^{\text {st }}$ edition, Dar Alshrouq, Amman.

Al-Lakani, Ahmed Hussein and Younis Radhwan. (1976). "Teaching the social subjects", Alam ALkitab, Cairo.

ALshirbiuni Fousi: Altantawi Iffat: "International introductory in the developing the teaching texts based on the developments of the twenty first century: the Anglo bookshop, Cairo.

Awad, Mohammad Abdul Ghani (1994). Teaching of the area unit using the module method and measuring its impact on the achievement for the students of the $11^{\text {th }}$ grade, unpublished Master thesis.

Faraj, Abdul Mawjoud Ali Hassan (1987). Using the module method in teaching the science text for the seventh grade of the elementary stage as a modern approach for ht individual learning.

Faraj, Abdul Mawjoud Ali Hassan (1987). Using the module method in teaching the science text for the seventh grade of the elementary stage as a modern approach for ht individual learning.

Jamil Abdul Rhman Abdul Salam (1998). "Self learning by the teaching modules" $3^{\text {rd }}$ edition, ALmanar for printing and auditing, Sanaa.

Jamil Abdul Rhman Abdul Salam (2000). "Self learning by the teaching modules modern attributes" $1^{\text {st }}$ edition, Dar Almanhaj for publishing and distribution, Amman.

Kasim Jaradat: "The balance of three teaching approaches, the compound of education, the conventional way in achievement and keeping for the students of the $1^{\text {st }}$ year of vocational careers in the community collages in the subject of educational psychology, in Jordan", unpublished Masters thesis, Jordan University, Amman,1985.

Lutfi Barakat Ahmed, (B, T). "Studies in developing the Arab homeland", Dar Al-Marekh, Al-Riahd.

Mohammad Hamdan: "approach with questions for modern teaching the dialogue and classroom questions, Dar Altarbiah Alhaditha, Amman.

Omer, Nawal Abdul Aleem (2001). The effectiveness of suggested teaching strategy for the treatment of the information to develop the creative thinking in science for the students of the middle school, unpublished Ph.D thesisleducation college/ Al-Munufia University. 
Rabaeh, Mohammad Hassan (2007). The effectiveness of the modules strategy based on perfection and research in gaining the chemical concepts for the students of the $10^{\text {th }}$ grade in Jordan, Ph.D thesis Amman Arab University for higher studies.

Rashed Ali (1408 Hijri). "The university and the university teaching" Dar ALshrouq, Jeddah.

Russel. T. Harlen, W., \& Wart, D. (1989). Children's ideas about evaporation, International journal of science education, 11, 566-576.

Tobji (1981). "The means of communication and technology in education". $9^{\text {th }}$ Edition, Dar-Alkalam, Kuwait.

Tobji, Hussein Hamdi (1981). "The planning to prepare the center of the teaching recourses", a seminar of the educational leaders of technology in the Arab countries, the Arab center, Kuwait.

Traci H. (2001). Why corporations are using the interactive multimedia for sales, marketing and training.

Zaidan, Mohammad Abdul Hameed (1998). The effectiveness of the teaching modules in the development of the production skills and the use of some teaching items for the students of technology classes, in the college of the quality education, unpublished Master thesisleducation college/ Al-Munufia University

Table1. Sample Distribution

\begin{tabular}{|l|l|l|l|l|l|l|}
\hline \multirow{2}{*}{ Group } & \multicolumn{2}{l}{ Male } & Female & \multicolumn{2}{l|}{ Total } \\
\cline { 2 - 7 } & classroom & students & classroom & students & classroom & students \\
\hline Experimental group & 1 & 39 & 1 & 48 & 2 & 87 \\
\hline Control group & 1 & 37 & 1 & 50 & 2 & 87 \\
\hline Total & 2 & 76 & 2 & 98 & 4 & 174 \\
\hline
\end{tabular}

Table 2.

\begin{tabular}{|l|l|}
\hline experimental group & Control group \\
\hline Pre-test via module approach & Pre-test with convention way \\
\hline Direct post test & Direct post test \\
\hline Postponed post test & Postponed post test \\
\hline
\end{tabular}

Table 3.

\begin{tabular}{|l|l|l|l|l|l|}
\hline The variation source & $\begin{array}{l}\text { Total of } \\
\text { squares }\end{array}$ & $\begin{array}{l}\text { Flexibility } \\
\text { rate }\end{array}$ & $\begin{array}{l}\text { Average of Total } \\
\text { of squares }\end{array}$ & $\begin{array}{l}\text { (F) } \\
\text { value }\end{array}$ & $\begin{array}{l}\text { Level } \\
\text { S S * }\end{array}$ \\
\hline Teaching method & 4.135 & 1 & 4.135 & 0.33 & 0.568 \\
\hline Student gender & 35.868 & 1 & 35.868 & 2.83 & 0.094 \\
\hline $\begin{array}{l}\text { The interaction of the teaching } \\
\text { approach by the gender }\end{array}$ & 0.700 & 1 & 0.700 & 0.055 & 0.814 \\
\hline Square entries (wrong) & 2152.214 & 170 & 2152.214 & & \\
\hline Grand total & 21920.374 & 173 & 12.673 & & \\
\hline
\end{tabular}


Table 4. The ANCOVA for the two study groups on the direct achievement test (total mark=50)

\begin{tabular}{|l|l|l|l|l|l|l|}
\hline Group & Gender & $\begin{array}{l}\text { Individual } \\
\text { Number }\end{array}$ & $\begin{array}{l}\text { The } \\
\text { average }\end{array}$ & $\begin{array}{l}\text { The total } \\
\text { number }\end{array}$ & $\begin{array}{l}\text { Total } \\
\text { average }\end{array}$ & $\begin{array}{l}\text { Standard } \\
\text { deviation }\end{array}$ \\
\hline \multirow{2}{*}{ Control } & Males & 37 & 30.81 & 87 & 31.89 & 8.64 \\
\cline { 2 - 4 } & Females & 50 & 32.68 & & & \\
\hline \multirow{2}{*}{ Experimental } & Males & 39 & 37.36 & 87 & 38.38 & 7.68 \\
\cline { 2 - 4 } & Females & 48 & 39.21 & & & \\
\hline
\end{tabular}

Table 5.

\begin{tabular}{|l|l|l|l|l|l|}
\hline The variation source & $\begin{array}{l}\text { Total of } \\
\text { squares }\end{array}$ & $\begin{array}{l}\text { Flexibility } \\
\text { rate }\end{array}$ & $\begin{array}{l}\text { Average of Total } \\
\text { of squares }\end{array}$ & (F) value & $\begin{array}{l}\text { Level of S S } \\
*\end{array}$ \\
\hline Teaching method & 1857.856 & 1 & 1857.856 & 27.784 & 0.000 \\
\hline Student gender & 147.882 & 1 & 147.882 & 2.212 & 0.139 \\
\hline $\begin{array}{l}\text { The interaction of } \\
\text { the } \begin{array}{c}\text { teaching } \\
\text { approach by the } \\
\text { gender }\end{array}\end{array}$ & 0.004 & 1 & 0.004 & 1.786 & 0.994 \\
\hline $\begin{array}{l}\text { Square entries } \\
\text { (wrong) }\end{array}$ & 11367.446 & 170 & 66.867 & & \\
\hline Grand total & 13349.96 & 173 & 77.176 & & \\
\hline
\end{tabular}

Table 6. The ANCOVA for the two study groups on the postponed achievement test according to the teaching method and gender of the students.

\begin{tabular}{|l|l|l|l|l|l|l|}
\hline Group & Gender & $\begin{array}{l}\text { Individual } \\
\text { Number }\end{array}$ & $\begin{array}{l}\text { The } \\
\text { average }\end{array}$ & $\begin{array}{l}\text { The total } \\
\text { number }\end{array}$ & $\begin{array}{l}\text { Total } \\
\text { average }\end{array}$ & $\begin{array}{l}\text { Standard } \\
\text { deviation }\end{array}$ \\
\hline \multirow{2}{*}{ Control } & Males & 37 & 27.19 & 87 & 27.36 & 9.1 \\
\cline { 2 - 5 } & Females & 50 & 27.48 & & 36.51 & 7.81 \\
\cline { 1 - 4 } Experimental & Males & 39 & 35.31 & 87 & & \\
\cline { 2 - 5 } & Females & 48 & 37.8 & & & \\
\hline
\end{tabular}

Table 7.

\begin{tabular}{|l|l|l|l|l|l|}
\hline The variation source & $\begin{array}{l}\text { Total of } \\
\text { squares }\end{array}$ & $\begin{array}{l}\text { Flexibility } \\
\text { rate }\end{array}$ & $\begin{array}{l}\text { Average of Total } \\
\text { of squares }\end{array}$ & (F) value & $\begin{array}{l}\text { Level of } \\
\text { S S * }\end{array}$ \\
\hline Teaching method & 3662.169 & 1 & 3662.169 & 50.762 & 0.000 \\
\hline Student gender & 65.431 & 1 & 65.431 & 0.907 & 0.342 \\
\hline $\begin{array}{l}\text { The interaction of the } \\
\text { teaching approach } \\
\text { by the gender }\end{array}$ & 37.827 & 1 & 37.827 & 0.524 & 0.470 \\
\hline $\begin{array}{l}\text { Square entries } \\
\text { (wrong) }\end{array}$ & 12264.443 & 170 & 72.144 & & \\
\hline Grand total & 16009.172 & 173 & & 92.539 & \\
\hline
\end{tabular}




\section{Index 1.}

\section{Instructions and Guidelines}

Dear student, in order to achieve the maximum benefits from this module, please follow these guidelines

- Read carefully the module title.

- Read the introduction carefully because it gives the module's content and purpose.

- Read the module's objectives because you have to achieve them after studying the module.

- Answer the pre-test questions while putting the following in mind.

- Answer this module's questions, never look into it until answering, because your answers determine your need to study this module.

- If you achieve $85 \%$ or more of total score, you may not need to study this module, however participate.

- Competency, carry out activities and report writing, help you r peers, your education is not restricted to the test only.

- If you score less than $85 \%$, thus you need to study the module.

- Read the module topics while carrying out the required activity.

- The Module includes some references at the end you may benefit from them.

- After completing this module you are required to take the post test.

- If you score more than $85 \%$, this means you mastered the module's content, be ready for the teacher' instructions.

- If you score less than $85 \%$ you should follow:

- You must know the questions you failed in them.

- Answer the questions one more time and never stop studding the module until you score $85 \%$.

- You may ask the teacher's help in this regard.

\section{Index 2.}

1. This test consist of (50) items.

2. Each item is followed by four answers, one of them is correct, place $(\mathrm{X})$ in the box that represent the correct answer for each item in the separate answer paper:

Example: the animal that became extinct as the surface of the earth is unsuitable for its growth is:

$$
\text { A- Lion B-Rabbit }
$$

C-Deer D-Dinosaur

\begin{tabular}{|l|l|l|l|l|}
\hline A & B & C & D & item \\
\hline & & & X & \\
\hline
\end{tabular}

Note that we have placed (x) in the box (D) which represent the correct answer.

3. If each item had more than one answer, it is considered wrong.

Example: the animal that became extinct as the surface of the earth Is unsuitable for its growth is:

$$
\text { A- Lion B-Rabbit }
$$

C-Deer D-Dinosaur

\begin{tabular}{|l|l|l|l|l|}
\hline A & B & C & D & item \\
\hline & $\mathrm{X}$ & & $\mathrm{X}$ & \\
\hline
\end{tabular}

Note that the alternative (D) represent the correct answer but the answer for this item is considered wrong as we placed $(\mathrm{X})$ in two places.

4. Your score for this test is the total of the correct answers.

2) Do not write anything on the questions paper and return it with the answer paper.

3) Answer the tests items and transfer the symbols on the answer paper. 
4) For each question there is 1 mark only.

5) The time of the test is 60 minutes.

\section{The answer paper}

Students name

Classroom:

Test time: school:

no. of correct answers:

date:

\begin{tabular}{|c|c|c|c|c|}
\hline \multicolumn{5}{|c|}{ The alternatives } \\
\hline Item no. & $\mathbf{A}$ & B & C & D \\
\hline \multicolumn{5}{|l|}{1.} \\
\hline \multicolumn{5}{|l|}{2.} \\
\hline \multicolumn{5}{|l|}{3.} \\
\hline \multicolumn{5}{|l|}{4.} \\
\hline \multicolumn{5}{|l|}{5.} \\
\hline \multicolumn{5}{|l|}{6.} \\
\hline \multicolumn{5}{|l|}{7.} \\
\hline \multicolumn{5}{|l|}{8.} \\
\hline \multicolumn{5}{|l|}{9.} \\
\hline \multicolumn{5}{|l|}{10.} \\
\hline \multicolumn{5}{|l|}{11.} \\
\hline \multicolumn{5}{|l|}{12.} \\
\hline \multicolumn{5}{|l|}{13.} \\
\hline \multicolumn{5}{|l|}{14.} \\
\hline \multicolumn{5}{|l|}{15.} \\
\hline \multicolumn{5}{|l|}{16.} \\
\hline 17. & & & & \\
\hline
\end{tabular}

\begin{tabular}{|l|l|l|l|l|}
\hline The alternatives & A & B & C & D \\
\hline Item no. & A & & & \\
\hline 18. & & & & \\
\hline 19. & & & & \\
\hline 20. & & & & \\
\hline 21. & & & & \\
\hline 22. & & & & \\
\hline 23. & & & & \\
\hline 24. & & & & \\
\hline 25. & & & & \\
\hline 26. & & & & \\
\hline 27. & & & & \\
\hline 28. & & & & \\
\hline 29. & & & & \\
\hline 30. & & & & \\
\hline
\end{tabular}




\begin{tabular}{|l|l|l|l|l|}
\hline 31. & & & & \\
\hline 32. & & & & \\
\hline 33. & & & & \\
\hline 34. & & & & \\
\hline 35. & & & & \\
\hline 36. & & & & \\
\hline 37. & & & & \\
\hline
\end{tabular}

\begin{tabular}{|c|c|c|c|c|}
\hline \multicolumn{5}{|c|}{ The alternatives } \\
\hline Item no. & A & B & $\mathrm{C}$ & D \\
\hline \multicolumn{5}{|l|}{38.} \\
\hline \multicolumn{5}{|l|}{39.} \\
\hline \multicolumn{5}{|l|}{40.} \\
\hline \multicolumn{5}{|l|}{41.} \\
\hline \multicolumn{5}{|l|}{42.} \\
\hline \multicolumn{5}{|l|}{43.} \\
\hline \multicolumn{5}{|l|}{44.} \\
\hline \multicolumn{5}{|l|}{45.} \\
\hline \multicolumn{5}{|l|}{46.} \\
\hline \multicolumn{5}{|l|}{47.} \\
\hline \multicolumn{5}{|l|}{48.} \\
\hline \multicolumn{5}{|l|}{49.} \\
\hline \multicolumn{5}{|l|}{50.} \\
\hline \multicolumn{5}{|l|}{51.} \\
\hline \multicolumn{5}{|l|}{52.} \\
\hline \multicolumn{5}{|l|}{53.} \\
\hline \multicolumn{5}{|l|}{54.} \\
\hline \multicolumn{5}{|l|}{55.} \\
\hline \multicolumn{5}{|l|}{56.} \\
\hline 57. & & & & \\
\hline
\end{tabular}

\section{Index (3)}

\section{The achievement test}

1. Animals that live in the sea, is one of the:
A- Vertebrates
B- invertebrates
C- mollusks D- Fish

2. Organisms that are reproduced by budding

A- Sponge B-Yeast C- hydra D- all the mentioned

3. the development of an organism form a side growth of the original organism is the reproduction by:
A- Budding
B-Regeneration
C- meioses D- fertilization

4. at the end meioses sex cells are produced with the number of:

A- 4 cell B- 6 cell C- 10 cell D- 46 cell 
5. The offspring of Amoeba are produced from cells with the number of :

A- one cell B- five cells C- four cells D- all the mentioned

6. the celled produced from the meiosis with the half number of chromosomes:

A- Sperm B-egg C-apple D- Gamites

7. plants are reproduced in many ways such as:

A- Apomixis B-spores C- D- all the mentioned

8. roots and stems are grown from the buds of the ground stem, is the reproduction with:
A- Rhizomes
B-grafts C- Tubers
D- bulbs

9. examples of plants which are reproduced by Rhizomes:

A- Lentil B-funaria C-pine D- mint

10. examples of plants which are reproduced by budding:
A- Mint B-palm tree
C- chickpea
D- grape

11. Moses, are avascular plants that are reproduced by
A- Seeds
B- grafting C- spores
D- bulbs

12. the process of delivery of the pollen to the body is called:
A- Stamen
B- ended C- carpel
D- pollination

13. the khanchar plant is vascular plant which are
A- Stamen
B- ended C- carpel
D- pollination

14. the masculinity organ in the flower is
A- Sting
B- penC- maysam
D- ovum

15. the part that is responsible for reproduction in the flower is
A- Flower
B- stem C- root
D- leaves

16. examples of stripped seed plants :
A- Pine
B- Khanchar
C- funaria
D- mosses

17. the modern ways of reproducing the plants asexually are:
A- Graft
B- tubers
C- onions
D- tissue planting

18. the farmers use the reproduction of plants by graft, tuber and onions, due to :
A- Keep the remaining B- gain of time C- keep the characters
D- all the mentioned

19. the fertilization process produce a cell called:
A- Fertilized egg
B- feminine gamites
C- peace of pollination
D- gamites

20. Bactria is reproduced in the middle area, this reproduction way is called
A- Renewal
B- meioses
C- budding
D- rhizomes

Place a circle for the letter of the correct answer of the following:-

21. one of the living organisms differ in its cell structure:
A- Green algae
B- organic bacteria C- bird
D- wheat

22. examples of the cystic fungi
A- Rotten bread fungal
B- Rotten fruit fungal
C- yeast
D- mushroom

23. the correct classification of the beans plant is :
A- avascular
B- seed plant
C- vascular
D- non-seed plant

24. invertebrate animals that the body consists of two layers of cells is:
A- Oyster
B- sponge C- tapeworm
D- planaria

25. Which of the invertebrate animals have constant body temperature? 
A- Lamprey B- salamander C- the viper D- pink bird

26. most types of Bacteria are surrounded by a layer called:

A- Cytoplasm B- plasma membrane C- loop chromosome D- portfolio

27. the bacteria that has its food from the photo synthesis is called:

A- Self feeding B- non- Self feeding C-parasitic D- pitch bacteria

28. the basics of cell unit is classified into four groups such as ciliary like:

A- Amoeba B- Paramecium C- flagellates D- spores

29. one of the diseases that infects the humans is Malaria, which is caused by:

A- Amoeba B- Plasmodium C- trypanosome D- all the mentioned

30. examples of the associating fungal is

A- Rotten bread fungal B- Rotten fruit fungal C-yeast D- mushroom

31. one of the principles the scientists use to classify the explants is:

A- Timber B- cortex C- vessels D- roots

32. the Khanchar plant is vessel plant that consists of:

33. the invertebrates form the following percentage of the Animal kingdom

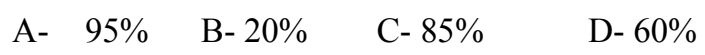

34. the snails living on the ground or sweet water or salty water belong to:

A- molluscus B- arthropods C-worms D- sponges

35. the scars worm is :

A- Flat B-cylindrical C- circular D- cyclic

36. the larger of the animal kingdom forming two thirds of the animals living on the earth and live in the deserts forests and seas are:
A- molluscus
B- arthropods
C- sponges
D- worms

37. the shark is considered

A- Cartilaginous B- bone C-agnatha D- lamprey

38. animals that have eyes consist of thousands of lenses that sense the light:

A- Insects B-crustaceous C- spiders D- many legs

39. the crocodile is classified as:

A- Reptile B-amphibians C- mammals D birds -

40. the creature that have no leg and crawls to move is :

A- Snake B- crocodile C- lizard D- turtle

41. the organisms with true nucleolus are classified into kingdoms:

$\begin{array}{ll}\text { A- } 4 \text { kingdoms } & \text { B- } 3 \text { kingdoms C- } 6 \text { kingdoms D- } 7 \text { kingdoms }\end{array}$

42. the organisms premature nebulous include:

A- Coccolithophorids B- fungal C- plants D- bacteria

43. algae that have chlorophyll are:

A- Brown B- golden C- red D- green

44. plasmodium from the premature single cell and are classified with in:

A- Root feet B- soreness C- cilia D- flagellate

45. the simplest animal form in structure and live in the bottom of the shallow seas are:-

A- Sponges B- worms C- arthritis D- algae

46. the frog is considered from the amphibian

A- Tailless B- with tail C- without legs D- reptile 
47. examples of cystic mammals :

A- Deer female B- kangaroo C- goat D- camels

48. one of the characteristic of the turtles that enables it to live on the ground :

A- their skin is covered with scales B- their eggs are covered with scales C-can breath with lungs D- all the mentioned

49. the largest vertebrates :-

A- Bone fish B- cartilage fish C- agnatha D- Repitiles

50. tapeworms are:

A- Flat worms B- cylindrical worms C- circular worms $\quad$ D- cyclic worms. 